\title{
MEMPREDIKSI FINANCIAL DISTRESS DENGAN BINARY LOGIT REGRESSION PERUSAHAAN TELEKOMUNIKASI
}

\author{
Tiara Widya Antikasari, Djuminah \\ Program Studi Magister Manajemen Universitas Sebelas Maret \\ Gedung IV Lantai 1 FEB, Jl. Ir. Sutami 36A Ketintang, Surakarta, 57126, Indonesia
}

\begin{abstract}
Keywords: activity ratio, binary logit regression, financial distress, leverage ratio, liquidity ratio, profitability ratio

JEL Classification: G30, G33

In this globalization era, sub-sector telecommunication industry has rapid development as time goes by with the number of customers' growth. However, its growth is not balanced with operational revenue development. Therefore, it is important to analyze the financial distress in telecommunication companies in order to avoid bankruptcy. This research aimed to investigate the effect of financial ratios to predict probability of financial distress. Financial ratios indicator used profitability ratio, liquidity ratio, activity ratio, and leverage ratio. The population in this research was telecommunication companies listed in the Indonesia Stock Exchange periods 20092016. Based on purposive sampling method, the criteria of financial distress in this study was measured by using net operation negative two years, while statistic analysis used was logistic regression with a significance level of $10 \%$. The result was that liquidity ratio (current ratio) and activity ratio (total asset turnover ratio) had a negative significant value, and profitability ratio (return on asset) and leverage ratio (debt to total asset) had positive significant value to predict financial distress.
\end{abstract}

Kata kunci: rasio aktivitas, binary logit regression, financial distress, rasio leverage, rasio likuiditas, rasio profitabilitas

\section{ABSTRAK}

Dalam era globalisasi ini, sub-industri telekomunikasi sektor memiliki perkembangan pesat seiring dengan jumlah pertumbuhan pelanggan, tetapi pertumbuhannya tidak diimbangi peningkatan dengan pendapatan operasionalnya. Oleh karena itu, penting untuk menganalisis financial distressperusahaan telekomunikasi agar terhindari dari kebangkrutan. Penelitian ini bertujuan untuk mengetahui pengaruh rasio keuangan untuk memprediksi probabilitas financial distress. Indikator rasio keuangan menggunakan rasio profitabilitas, rasio likuiditas, rasio aktivitas, dan rasio leverage. Populasi dalam penelitian ini adalah perusahaan telekomunikasi yang terdaftar di Bursa Efek Indonesia 20092016. Berdasarkan metode purposive sampling, adapun kriteria financial distress dalam penelitian ini diukur dengan menggunakan operasi bersih negatif dua tahun, sementara analisis statistik yang digunakan software SPSS 20 regresi logistik dengan tingkat signifikansi 10\%. Hasilnya, rasio likuiditas (current ratio) dan rasio aktivitas (rasio total asset turnover) memiliki nilai negatif yang signifikan, dan rasio profitabilitas (return on asset) dan rasio leverage (debt to total asset) memiliki nilai positif yang signifikan untuk memprediksi kesulitan keuangan. 


\section{Jurnal Keuangan dan Perbankan | KEUANGAN}

Vol. 21, No. 2, April 2017: 265-275

Di Indonesia, sektor industri telekomunikasi merupakan salah satu sektor industri yang mempunyai pengaruh besar terhadap kegiatan ekonomi. Hal ini karena komunikasi adalah kegiatan utama dalam aktivitas bisnis dan memberikan kontribusi kepada perekonomian Indonesia cukup besar. Pada tahun 2014 ada 9 perusahaan sektor telekomunikasi yang tercatat dalam Indonesian Capital Market Directory (ICMD). Yang terdiri dari penyedia layanan operator seluler, produksi retail peralatan komunikasi, dan tower leasing industry. Operator seluler antara lain Telkomsel, Indosat, XL, Bakrie Telcom, dan Smartfren.

Menurut cacatan ATSI (Asosiasi Telekomunikasi Indonesia) jumlah pengguna seluler di Indonesia hingga bulan Juni 2010 diperkirakan mencapai 180 juta pelanggan atau sekitar $80 \%$ populasi penduduk. Dari 180 juta pelanggan seluler tersebut, sebanyak $95 \%$ adalah pelanggan prabayar. Akibat kebijakan pemerintah tentang penurunan tarif pada awal 2008 dan gencarnya perang tarif para operator yang makin gencar, kualitas layanan operator di Indonesia semakin terus memburuk terutama pada jam sibuk.

Meskipun jumlah pelanggan dari kelima provider tersebut cenderung terlihat mengalami kenaikan. Namun, jika dilihat dari tingkat pertumbuhannya, perusahaan sektor telekomunikasi mengalami penurunan. Tingkat pertumbuhan tersebut diperoleh dari selisih antara persentase tingkat pertumbuhan jumlah pelanggan tahun yang diamati dengan persentase tingkat pertumbuhan jumlah pelanggan tahun sebelumnya. Kondisi ini menunjukkan adanya persaingan yang ketat di bidang industri telekomunikasi yang dapat dilihat pada Tabel 1 (Irfan \& Yuniati, 2014).

Situasi persaingan yang sangat ketat tersebut tidak membuat perjalanan bisnis dari suatu perusahaan selalu menunjukkan perkembangan usaha, tetapi pada suatu ketika ada saatnya perusahaan mengalami kesulitan keuangan. Persaingan antar perusahaan yang semakin ketat menyebabkan biaya yang akan dikeluarkan oleh perusahaan akan semakin tinggi, hal ini akan memengaruhi kinerja perusahaan. Apabila suatu perusahaan tidak mampu untuk bersaing maka perusahaan tersebut akan mengalami kerugian, yang pada akhirnya bisa membuat suatu perusahaan mengalami financial distress bahkan kebangkrutan (Widarjo \& Setyawan, 2009).

Menurut Afriyeni (2012) financial distress terjadi sebelum perusahaan menghadapi kegagalan ataupun kebangkrutan.Kondisi financial distress merupakan kondisi dimana keuangan perusahaan dalam keadaan tidak sehat atau krisis. Financial distress juga didefinisikan sebagai ketidakmampuan

Tabel 1. Pertumbuhan Jumlah Pelanggan Perusahaan Operator Seluler Terbesar di Indonesia

\begin{tabular}{cccc}
\hline Tahun & $\begin{array}{c}\text { PT. Teleko-munikasi } \\
\text { Selular }\end{array}$ & PT. Indosat Tbk & PT. XL Axiata Tbk \\
\hline 2007 & 47,8 juta & 18,02 juta & 15,4 juta \\
2008 & 65,3 juta & 35 juta & 26 juta \\
2009 & 82 juta & 33,1 juta & 31,4 juta \\
2010 & 100 juta & 39,1 juta & 40,1 juta \\
2011 & 107 juta & 52,1 juta & 46,5 juta \\
Effects Test & Statistic & d.f. & Prob. \\
Cross-section F & 2,752960 & $(5,29)$ & 0,0374 \\
Test Summary & Chi-Sq. Statistic & Pri-Sq. d.f. & 7 \\
Cross-section random & 5,027741 & & 0,6566 \\
\hline
\end{tabular}

Sumber: Irfan \& Yuniati (2014). 


\section{Memprediksi Financial Distress dengan Binary Logit Regression Perusahaan Telekomunikasi}

Tiara Widya Antikasari \& Djuminah

perusahaan untuk membayar kewajiban-kewajiban financial yang telah jatuh tempo (Beaver et al., 2011). Perusahaan yang mengalami kondisi financial distress dapat dilihat atau ditentukan oleh berbagai faktor, yaitu: (1) selama 2 tahun mengalami laba bersih operasi (net operating income) negatif dan selama lebih dari satu tahun tidak melakukan pembayaran dividen (Almilia \& Kristijadi, 2003). Adanya pemberhentian tenaga kerja atau menghilangkan pembayaran dividen (Hill, et al. (1996). (3) Perusahaan tersebut memiliki kinerja yang menunjukkan laba operasinya negatif, laba bersih negatif, nilai buku ekuitas negatif, dan perusahaan yang melakukan merger. (4) Mengukur financial distress dengan cara adanya arus kas yang lebih kecil dari utang jangka panjang saat ini (Whitaker, 1999). (5) Economic Value Added (EVA) negatif (Pasaribu, 2008).

Model financial distress perlu untuk dikembangkan, karena dengan mengetahui kondisi financial distress perusahaan sejak dini diharapkan dapat melakukan tindakan-tindakan yang mengantisipasi menuju arah kebangkrutan. Brahmana (2007) mengungkapkan bahwa ada dua motif dilakukannya penelitian tentang financial distress suatu perusahaan. Pertama adalah menguji hubungan dan pengaruh antar variabel faktor keuangan dan pengukuran kegagalan atau kebangkrutan. Kedua adalah mengembangkan model dalam peramalan atau prediksi kebangkrutan. Dalam penelitian ini dilakukan berkaitan dengan motif yang pertama yaitu menguji pengaruh rasio keuangan terhadap financial distress perusahaan. Penelitian ini menggunakan rasio keuangan keuangan dari informasi laporan laba rugi dan neraca. Rasio yang digunakan dalam penelitian ini adalah rasio profitabilitas, likuiditas, aktivitas, dan leverage.

\section{PENGEMBANGAN HIPOTESIS}

\section{Rasio Profitabilitas dan Financial Distress}

Menurut Putra (2009), rasio profitabilitas adalah rasio yang mengukur seberapa efektivitas manajemen dan eksekutif perusahaan yang dibuktikan dengan kemampuan menciptakan nilai keuntungan. Menurut Widarjo \& Setiawan (2009) dengan adanya efektivitas dari penggunaan asset perusahaan maka akan mengurangi biaya yang dikeluarkan oleh perusahaan. Perusahaan akan memperoleh penghematan dan akan memiliki kecukupan dana untuk menjalankan usahanya. Kecukupan dana tersebut maka kemungkinan perusahaan mengalami financial distress akan menjadi lebih kecil. Semakin tinggi kemampuan perusahaan menghasilkan laba, maka semakin kecil kemungkinan perusahaan mengalami financial distress. Dalam penelitian ini rasio profitabilitas diukur dengan ROA, menunjukkan kemampuan dari modal yang diinvestasikan dalam keseluruhan aktiva untuk menghasilkan keuntungan netto. Rasio profitabilitas mempunyai pengaruh negatif dan signifikan dalam memprediksi financial distress (Lawrence et al., 2015). Penelitian yang dilakukan Al-khatib \& Horani (2012) mengungkapkan bahwa profitabilitas tidak berpengaruh terhadap financial distress. Rasio Return of Asset (ROA) dapat memprediksi kemungkinan terjadinya financial distress dengan pengaruh positif (Azwar, 2015). Rasio ini digunakan untuk mengukur efektifitas perusahaan dalam mengelola aktivanya. Jumlah aktiva yang terlalu banyak akan menimbulkan biaya modal yang besar, sehingga akan menekan keuntungan. Sebaliknya aktiva yang terlalu kecil akan menyebabkan hilangnya penjualan yang menguntungkan.

$\mathrm{H}_{1}$ : rasio return on asset berpengaruh negatif terhadap financial distress.

\section{Rasio Likuiditas dan Financial Distress}

Menurut Syamsuddin (2004), rasio likuiditas merupakan rasio yang mengukur kemampuan perusahaan untuk membayar utang yang segera harus dipenuhi dengan aktiva lancar. Azwar (2015) mengungkapkan bahwa perusahaan dalam keadaan likuid apabila perusahaanmempunyai alat pembayaran atau aktiva lancar yang lebih besar 


\section{Jurnal Keuangan dan Perbankan | KEUANGAN}

Vol. 21, No. 2, April 2017: 265-275

daripada utang lancarnya dan mampu memenuhi kewajiban keuangannya tepat pada waktunya. Semakin tinggi rasio likuiditas maka semakin kecil kemungkinan perusahaan mengalami financial distress. Dalam penelitian ini rasio likuiditas diukur dengan current ratio yang menunjukkan kemampuan untuk membayar utang yang segera harus dipenuhi dengan aktiva lancar. Hasil penelitian Nurfajrina et al. (2016) bahwa rasio likuiditas yang diukur current ratio dan cash ratio tidak berpengaruh terhadap financial distress. Penelitian yang dilakukan Ahmad (2013) menunjukkan bahwa rasio likuiditas berpengaruh signifikan terhadap financial distress.

$\mathrm{H}_{2}$ : rasio current ratio berpengaruh negatif terhadap financial distress.

\section{Rasio Aktivitas dan Financial Distress}

Menurut Riyanto (2011) rasio aktivitas yaitu rasio-rasio yang digunakan untuk mengukur sampai seberapa besar efektivitas perusahaan dalam mengerjakan sumber-sumber dananya (inventory turnover, total asset turnover, average collection period dan lain sebagainya). Rasio aktivitas dalam penelitian ini diukur menggunakan total asset turnover, dimana bertujuan mengukur efektifitas perusahaan dalam mengelola aktivanya. Penelitian yang dilakukan Pervan et al. (2011) menungkapkan bahwa rasio aktivitas tidak berpengaruh terhadap financial distress. Penelitian yang dilakukan Hidayat \& Merianto (2014) menunjukkan bahwa rasio aktivitas berpengaruh negatif terhadap financial distress.

$\mathrm{H}_{3}$ : rasio total asset turnover berpengaruh negatif terhadap financial distress.

\section{Rasio Leverage dan Financial Distress}

Menurut Kasmir (2008), rasio leverage merupakan rasio yang digunakan untuk mengukur sejauhmana aktiva perusahaan dibiayai oleh utang.
Rasio ini dapat dihitung berdasarkan informasi dari neraca, yaitu di pos-pos aktiva dan pos-pos utang. Menurut Azwar (2015) perusahaan yang memiliki tingkat utang yang lebih besar akan lebih mudah mengalami financial distress maupun kebangkrutan dibandingkan perusahaan yang memiliki utang lebih sedikit. Dalam penelitian ini rasio leverage diukur dengan debt to total asset rasio ini menunjukkan beberapa dari aktiva yang digunakan untuk menjamin utang. Dalam penelitian yang dilakukan oleh Hapsari (2012) bahwa rasio leverage berpengaruh terhadap financial distress. Penelitian yang dilakukan Widhiari \& Merkusiwati (2015) mengungkapkan bahwa rasio leverage tidak berpengaruh terhadap financial distress.

$\mathrm{H}_{4}$ : rasio debt to total asset berpengaruh positif terhadap financial distress.

Altman (1968) menggunakan rasio-rasio keuangan untuk memprediksi kebangkrutan suatu perusahaan. Dengan meneliti sebanyak 66 perusahaan yang ada di Amerika menggunakan pendekatan Multivariate Discriminant Analysis (MDA) yang sering dikenal dengan metode Z-score Altman. Adanya kekurangan yang seringkali dijumpai pada pendekatan MDA dalam hal asumsi normalitas data dan dispersi kelompok (group dispersion). Hal ini menyebabkan timbulnya bias terhadap tingkat signifikansi dan estimated errors (Ohlson, 1980).

Metode Binary Logit Regression (BLR) untuk meramalkan kebangkrutan perusahaan yang pertamakali dilakukan oleh Ohlson (1980). Penelitiannya menunjukkan bahwa ukuran perusahaan (size), struktur keuangan (total liabilities to total asset), performance dan current liquidity adalah kelompok rasio (variabel) penentu yang signifikan di dalam meramalkan kebangkrutan. Agrawal \& Mahesawari (2016) mengungkapkan bahwa metode logistic regression lebih akurat dibandingkan dengan metode Z-score dengan tingkat akurasi klasifikasi total sebesar $63,3 \%$, hal ini didukung oleh penemuan Giampaoli et al. (2016). 


\section{Memprediksi Financial Distress dengan Binary Logit Regression Perusahaan Telekomunikasi}

Tiara Widya Antikasari \& Djuminah

\section{METODE}

\section{Populasi, Sampel, dan Sumber Data}

Populasi merupakan keseluruhan objek yang memenuhi syarat tertentu dan berkaitan dengan masalah yang diteliti. Populasi yang diamati dalam penelitian ini adalah perusahaan telekomunikasi yang terdaftar di Bursa Efek Indonesia dari tahun 2009-2016.Pemilihan sampel dilakukan dengan teknik purposive sampling, yaitu pemilihan sampel yang didasarkan pada kriteria tertentu. Kriteria yang akan digunakan adalah: (1) Perusahaan sektor telekomunikasi yang terdaftar di BEI. (2) Laporan keuangan perusahaan lengkap dan telah diaudit. (3) Komponen-komponen yang diperlukan dalam proses perhitungan tercantum jelas di laporan keuangan.

Berdasarkan pada kriteria pemilihan sampel, maka perusahaan yang memenuhi kriteria dan dijadikan sampel dalam penelitian ini adalah 8 perusahaan yang dapat dilihat pada Tabel 2.Penelitian ini menggunakan data sekunder tentang laporan keuangan perusahaan yang bersumber dari www.idx.co.id tahun 2009 sampai dengan 2016.
Tabel 2. Sampel Penelitian

\begin{tabular}{ll}
\hline Nama & Kode \\
\hline PT Bakrie Telecom Tbk & BTEL \\
PT Indosat Tbk & ISAT \\
PT Inovisi Infracom Tbk & INVS \\
PT Smartfren Telecom Tbk & FREN \\
PT Telekomunikasi Indonesia (Persero) & TLKM \\
Tbk & \\
PT Tower Bersama Infrastructure Tbk & TBIG \\
PT Trikomsel Oke Tbk & \\
PT XL Axiata Tbk & EXCL \\
\hline
\end{tabular}

Sebelum melakukan pengujian hipotesis penelitian terlebih dahulu dilakukan uji kelayakan dari model logit regression yang digunakan (Azwar, 2015). Uji yang dilakukan adalah sebagai berikut: (1) menilai kelayakan model regresi: nilai goodnest of test yang diukur dengan nilai Chi-Square pada bagian bawah uji Hosmer and Lemeshow harus menunjukkan angka probabilitas $>0.1$, artinya tidak ada perbedaan yang nyata antara klasifikasi yang diprediksi dengan klasifikasi yang diamati. Hal ini berarti model regresi logistik layak dipakai untuk analisis selanjutnya. (2) Menilai keseluruhan model (overall model fit): dari angka -2 LogLikehood, dimana

Tabel 3. Operasionalisasi dan Pengukuran Variabel

\begin{tabular}{|c|c|c|}
\hline Variabel & Proksi & Pengukuran \\
\hline \multicolumn{3}{|l|}{ Variabel Dependen } \\
\hline Financial Distress & $\begin{array}{l}0=\text { Financial Distress } \\
1=\text { Non Financial Distress }\end{array}$ & $\begin{array}{l}\text { Financial distress jika selama dua tahun berturut- } \\
\text { turut mengalami laba bersih operasi (net operating } \\
\text { income) dan dikategorikan } 0 \text {, sedangkan } \\
\text { perusahaan yang tidak mengalami laba bersih } \\
\text { operasi negatif selama dua tahun berturut-turut } \\
\text { tidak dikategorikan mengalami financial distress } \\
\text { dikategorikan } 1 \text {. }\end{array}$ \\
\hline \multicolumn{3}{|l|}{ Variabel Independen } \\
\hline Rasio profitabilitas & Return On Asset & $R O A=\frac{E B I T}{\text { Jumlah aktiva }}$ \\
\hline Rasio likuiditas & Current Ratio & $C R=\frac{\text { Aktiva Lancar }}{\text { Hutang Lancar }}$ \\
\hline Rasio aktivitas & Total Asset turnover & $A T O=\frac{\text { Penjualan neto }}{\text { Jumlah aktiva }}$ \\
\hline Rasio leverage & Debt to Total Asset (DTA). & DTA $\frac{\text { Total Hutang }}{\text { Total Aktiva }}$ \\
\hline
\end{tabular}




\section{Jurnal Keuangan dan Perbankan | KEUANGAN}

Vol. 21, No. 2, April 2017: 265-275

pada awal (Block Number $=0)$ angka -2 Log Likehood harus turun pada Block Number $=1$. Penurunan ini dimana Likehood pada regresi logistik menunjukkan model regresi yang lebih baik. (3) Uji koefisien determinasi digunakan untuk mengetahui seberapa besar variabilitas variabel-variabel independen mampu memperjelas variabilitas variabel dependen. Koefisien determinasi pada regresi logistik dapat dilihat pada nilai Nagelkarke $R$ Square. (4) Matriks kualifikasi akan menunjukkan kekuatan prediksi dari model regresi untuk memprediksi kemungkinan suatu perusahaan mengalami financial distress. Akurasi prediksi dapat dilihat di tabel tabulasi silang (Classification Table).

\section{Model analisis regresi logistik}

Metode analisis yang digunakan dalam penelitian ini adalah regresi binary logit regression.Model logit secara sederhana didefinisikan sebagai model regresi non-linear yang menghasilkan persamaan di mana variabel dependen bersifat kategorikal. Kategori paling mendasar dari model tersebut menghasilkan binary values seperti angka 0 dan 1 . Berdasarkan penelitian yang dilakukan oleh Azwar (2015) model analisinya adalah sebagai berikut:

$$
\operatorname{Ln} \frac{P}{P-1}=\boldsymbol{\beta} 0+\boldsymbol{\beta} 1 \mathrm{ROA}+\boldsymbol{\beta} 2 \mathrm{DTA}+\boldsymbol{\beta} 3 \mathrm{ATO}+\boldsymbol{\beta} 4 \mathrm{CR}
$$

\section{Keterangan:}

$\mathrm{Ln}=\log$ dari perbandingan antara peluang $\mathrm{fi}_{-}$ nancial distress dan peluang non financial distress

$\mathrm{a}=$ konstanta

b1 = koefisien regresi dari ROA

b2 = koefisien regresi dari DTA

b3 = koefisien regresi dari ATO

$\mathrm{b} 4=$ koefisien regresi dari $\mathrm{CR}$

Tingkat signifikansi (level of significant) yang digunakan dalam penelitian ini adalah sebesar $90 \%$ $(\alpha=0,1)$, karena dinilai relatif kuat dalam menguji hubungan variabel-variabel yang diuji atau menunjukkan bahwa korelasi antar variabel cukup nyata (Azwar, 2015). Tingkat signifikansi 0,1 artinya kemungkinan besar dari hasil penarikan kesimpulan mempunyai probabilitas sebesar $90 \%$ atau toleransi kesalahan sebesar $10 \%$.

\section{Uji Hipotesis}

Selanjutnya untuk pembuktian hipotesis penelitian, pengujian juga akan dilakukan untuk melihat tingkat signifikansi variabel independen (rasio keuangan) dalam memengaruhi atau memprediksi variabel terikat (kondisi financial distress) dengan koefisien regresi. Menurut Ghozali (2006) uji ini pada dasarnya menunjukkan seberapa jauh pengaruh satu variabel independen secara individual dalam menerangkan variabel dependen. Pengujian dilakukan dengan menggunakan signifikansi level 0,1 ( $\alpha=10 \%)$. Kriteria hipotesis dilakukan dengan dengan cara sebagai berikut: (1) Jika nilai signifikansi (Sig.) > 0,1 maka hipotesis ditolak atau koefisien regresi tidak signifikan. Hal ini berarti secara parsial variabel independen tidak mempunyai pengaruh secara signifikan terhadap variabel dependen. (2) Jika nilai signifikansi (Sig.) $\leq 0,1$ maka hipotesis diterima atau koefisien regresi signifikan. Hal ini berarti secara parsial variabel independen tersebut mempunyai pengaruh yang signifikan terhadap variabel dependen.

\section{HASIL}

\section{Hasil Uji Kelayakan Model (Goodness of Fit Test)}

Berdasarkan Tabel 4 pada uji hosmer and lemeshow test diperoleh nilai Chi Square sebesar 3.890 dengan nilai sig sebesar 0.867. Dari hasil tersebut terlihat bahwa nilai Sig lebih besar yaitu 0.867> 0.1 , artinya tidak ada perbedaan yang nyata antara klasifikasi yang diprediksi dengan klasifikasi yang 
diamati.Hal ini berarti model regresi logistik layak dipakai untuk analisis selanjutnya. Estimasi chisquare ditujukan untuk mengetahui pengaruh dari rasio profitabilitas, likuiditas, aktivitas, dan leverage dalam memprediksi financial distress.

Tabel 4. Hasil Uji Kelayakan Model (Goodness of Fit Test) dengan Hosmer and Lemeshow Test

\begin{tabular}{cccc}
\hline Step & Chi-square & df & Sig. \\
\hline 1 & 3.890 & 8 & .867 \\
\hline
\end{tabular}

\section{Hasil Uji Keseluruhan Model (Overall Model} Fit)

Untuk mengetahui apakah variabel bebas yang ditambahkan ke dalam model dapat secara signifikan memperbaiki model digunakan statistik -2LogL. Pada Block Number $=0$ (Beginning Block) yaitu model pertama hanya dengan konstanta tanpa adanya variabel bebas diperoleh nilai -2 Log Likehood sebesar 66.542. Tabel 5 terlihat bahwa Block Number Opada Block Number 1 turun menjadi 23.219.

Tabel 5. Uji Keseluruhan Model (Overall Model Fit)

\begin{tabular}{ll}
\hline Model: & \\
\hline Block & -2 Log likelihood \\
Block number 0 & 66.542 \\
Block number 1 & 23.219 \\
\hline
\end{tabular}

Berdasarkan Tabel 5, nilai -2 log likelihood awal (hasil block number 0) sebesar 66,542 dan nilai -2 log likelihood hasil block number 1 sebesar 23,219. Dengan adanya penurunan nilai -2 log likelihood tersebut maka hal ini menunjukkan bahwa maka model yang digunakan adalah model regresi yang baik dan layak digunakan.

\section{Uji Koefisien Determinasi}

Koefisien determinasi digunakan untuk mengetahui seberapa besar variabilitas variabel- variabel independen mampu memperjelas variabilitas variabel dependen.Koefisien determinasi pada regresi logistik dapat dilihat pada nilai Nagelkarke R Square. Adapun hasil nilai Cox E Snell $R$ Square dapat ditampilkan pada Tabel 6 .

Tabel 6. Model Summary

\begin{tabular}{cccc}
\hline Step & $\begin{array}{c}-2 \text { Log } \\
\text { likelihood }\end{array}$ & $\begin{array}{c}\text { Cox \& Snell } \\
\text { R Square }\end{array}$ & $\begin{array}{c}\text { Nagelkerke R } \\
\text { Square }\end{array}$ \\
\hline 1 & $23.219^{a}$ & 0,594 & 0,793 \\
\hline
\end{tabular}

Tampak pada Tabel 6, nilai chi-square yang merupakan selisih nilai -2 Log likelihood sebelum variabel independen masuk model dan -2 Log likelihood setelah variabel independen masuk model $=$ 23.219 .

Nilai chi-square $=23.219>$ chi-square tabel pada df 4 (jumlah variabel independen 4) yaitu 7.779 atau dengan signifikansi sebesar $0,1(<0,1)$ sehingga menolak Ho, yang menunjukkan bahwa penambahan variabel independen dapat memberikan pengaruh nyata secara simultan terhadap model.

Dari Tabel 6, pada model summary, variabel independen dalam menjelaskan variabel dependen, dengan menggunakan nilai Nagelkerke $R$ Square. Nilai Nagelkerke R Square sebesar 0,793, menunjukkan bahwa kemampuan variabel independen dalam menjelaskan variabel dependen adalah sebesar 0,793 atau 79,3 persen. Atau dengan kata lain bahwa 79,3 persen dari variabel dependen (financial distress dan non-distress) dapat diprediksi oleh variabel independen berupa rasio-rasio keuangan: ROA, CR, ATO, dan DTA. Sedangkan sisanya sebesar 20,7 persen dapat diprediksi dan dijelaskan oleh variabel-variabel independen lainnya yang tidak dimasukkan dalam model.

\section{Matriks Kualifikasi}

Matriks kualifikasi akan menunjukkan kekuatan prediksi dari model regresi untuk memprediksi kemungkinan suatu perusahaan meng- 


\section{Jurnal Keuangan dan Perbankan | KEUANGAN}

Vol. 21, No. 2, April 2017: 265-275

alami financial distress. Daya klasifikasi dapat ditunjukkan dengan tabel tabulasi silang antara prediksi model regresi logistik dan hasil observasi yang ditampilkan pada Tabel 7.

Tabel 7. Tabulasi Silang

\begin{tabular}{|c|c|c|c|c|}
\hline & \multirow{3}{*}{ Observed } & \multicolumn{3}{|c|}{ Predicted } \\
\hline & & \multicolumn{2}{|c|}{ EPS } & \multirow{2}{*}{$\begin{array}{c}\text { Percentage } \\
\text { Correct }\end{array}$} \\
\hline & & FD & NFD & \\
\hline \multirow{3}{*}{$\begin{array}{l}\text { Step } \\
1\end{array}$} & \multirow{2}{*}{ EPS } & 21 & 3 & 87,5 \\
\hline & & 3 & 21 & 87,5 \\
\hline & $\begin{array}{l}\text { Overall } \\
\text { Percentage }\end{array}$ & & & 87,5 \\
\hline
\end{tabular}

Berasarkan Tabel 7 hasil overall classification, persentase kebenaran untuk perusahaan yang mengalami FD (financial distress) dan NFD (non financial distress) memilki angka prediksi yang sama yaitu sebesar $87,5 \%$, yaitu 21 observasi diprediksikan secara benar dan hanya 3 observasi diprediksikan sebaliknya.

\section{Hasil Uji Analisis Regresi Logistik}

Untuk menguji hipotesis digunakan uji regresi logistik yang dilakukan terhadap semua variabel yaitu profitabilitas, likuiditas, aktivitas dan leverage dalam memprediksi financial distress. Berdasarkan Tabel 8 hasil pengujian adalah sebagai berikut:

$$
\begin{aligned}
\mathrm{Y}= & -15,751+0,812 \mathrm{ROA}+(-2,059) \mathrm{CR}+31,127 \mathrm{DTA} \\
& +(-7,345) \text { ATO }
\end{aligned}
$$

Angka yang dihasilkan dari pengujian tersebut dapat dijelaskan dengan hasil uji hipotesis secara statistik pada Tabel 8 .

Tabel 8. Uji Hipotesis

\begin{tabular}{lrccc}
\hline & \multicolumn{1}{c}{ B } & Wald & df & Sig. \\
\hline CR & $-2,059$ & 5,677 & 1 & 0,017 \\
DTA & 31,127 & 5,897 & 1 & 0,015 \\
ATO & $-7,345$ & 3,823 & 1 & 0,051 \\
ROA & 0,812 & 6,868 & 1 & 0,009 \\
Constant & $-15,751$ & 4,996 & 1 & 0,025 \\
\hline
\end{tabular}

Hasil pengujian hipotesis 1 rasio profitabilitas yang diukur dengan return on asset (ROA) menunjukkan koefisien regresi 0,812 dan nilai signifikansi sebesar 0,009. Karena koefisien regresi bernilai positif. Nilai signifikansi 0,009 < 0,1 maka dari hasil ini berarti Ho ditolak dan Ha diterima, artinya rasio profitabilitas mempunyai pengaruh postif yang signifikan dalam memprediksi financial distress. Namun hasil ini tidak mendukung hipotesis yang menyatakan rasio profitabilitas berpengaruh negatif.

Hasil pengujian hipotesis 2 rasio likuiditas yang diukur dengan current asset (CR) menunjukkan koefisien regresi -2,059 dan nilai signifikansi sebesar 0,017. Karena koefisien regresi bernilai negatif dengan nilai signifikansi 0,017 < 0,1 maka dari hasil ini berarti Ho ditolak dan Ha diterima, rasio likuiditas mempunyai pengaruh yang signifikan dalam memprediksi financial distress.

Hasil pengujian hipotesis 3 rasio aktivitas yang diukur dengan total asset turnover (ATO) menunjukkan koefisien regresi -7,345 dan nilai signifikansi sebesar 0,051. Karena koefisien regresi bernilai positif nilai signifikansi 0,051 <0,1 maka dari hasil ini berarti Ho ditolak dan Ha diterima, artinya rasio aktivitas mempunyai pengaruh yang signifikan dalam memprediksi financial distress.

Hasil pengujian hipotesis 4 rasio leverage yang diukur dengan debt to total asset (DTA) menunjukkan koefisien regresi 31,127 dan nilai signifikansi sebesar 0,015. Karena koefisien regresi bernilai positif nilai signifikansi 0,015 $<0,1$ maka dari hasil ini berarti Ho ditolak dan Ha diterima, artinya rasio leverage mempunyai pengaruh yang signifikan dalam memprediksi financial distress.

\section{PEMBAHASAN}

\section{Rasio Profitabilitas}

Melalui regresi logistik telah diketahui bahwa profitabilitas memiliki pengaruh signifikan dalam memprediksi financial distress. Hasil dari pengujian 


\section{Memprediksi Financial Distress dengan Binary Logit Regression Perusahaan Telekomunikasi}

Tiara Widya Antikasari \& Diuminah

tersebut menunjukkan bahwa profitabilitas memiliki pengaruh signifikan dan positif dalam memprediksi financial distress. Hasil ROA dapat memprediksi kemungkinan terjadinya financial distress dengan pengaruh positif. Jumlah aktiva yang terlalu banyak akan menimbulkan biaya modal yang besar, sehingga akan menekan keuntungan. Sebaliknya aktiva yang terlalu kecil akan menyebabkan hilangnya penjualan yang menguntungkan. Semakin besar rasio yang didapat maka semakin baik karena perusahaan semakin cepat mengubah persediaannya menjadi kas sehingga kemungkinan terjadinya kesulitan keuangan semakin kecil. Hasil ini tidak sejalan hipotesis yang menduga rasio profitabilitas berpengaruh negatif dan tidak sejalan dengan penelitian Azwar (2015) yang justru menemukan bahwa rasio ROA memiliki pengaruh negatif terhadap probabilitas financial distress.

\section{Rasio Likuiditas}

Melalui regresi logistik telah diketahui bahwa likuiditas memiliki pengaruh yang signifikan dalam memprediksi financial distress. Hasil dari pengujian tersebut menunjukkan bahwa likuiditas memiliki pengaruh signifikan dan negatif dalam memprediksi financial distress. Hal ini berarti perusahaan yang memiliki CR maka perusahaan tersebut lebih likuid, yang menunjukkan kemampuan perusahaan melunasi kewajiban jangka pendeknya dan mampu membiayai kegiatan operasional perusahaan tersebut. Dengan adanya biaya untuk mendanai kegiatan operasional tersebut maka perusahaan mampu berproduksi dan menjalankan aktivitas operasional perusahaan dengan baik dan kemungkinan perusahaan mengalami financial distress menjadi kecil.Hasil penelitian ini sesuai dengan penelitian Ahmad (2013) yang menyatakan bahwa likuiditas berpengaruh signifikan dalam memprediksi kondisi financial distress.

\section{Rasio Aktivitas}

Melalui regresi logistik telah diketahui bahwa rasio aktivitas memiliki pengaruh yang signifikan dalam memprediksi financial distress. Hasil dari pengujian tersebut menunjukkan bahwa rasio aktivitas memiliki pengaruh signifikan dan negatif dalam memprediksi financial distress. Hal ini berarti perusahaan yang memiliki ATO maka efektifitas perusahaan mengelola aktivanya lebih bagus.Jadi semakin besar rasio ini maka semakin baik yang berarti bahwa aktiva dapat lebih cepat berputar dan meraih laba dan menunjukkan semakin efisien penggunaan seluruh aktiva dalam menghasilkan penjualan.Maka perusahaan semakin cepat mengubah persediaannya menjadi kas sehingga kemungkinan terjadinya financial distress semakin kecil. Hasil ini sejalan dengan penelitian yang dilakukan oleh Hidayat \& Merianto (2014).

\section{Rasio Leverage}

Melalui regresi logistik telah diketahui bahwa rasio leverage memiliki pengaruh signifikan dalam memprediksi financial distress. Hasil dari pengujian tersebut menunjukkan bahwa profitabilitas memiliki pengaruh signifikan dan positif dalam memprediksi financial distress dengan nilai signifikansi sebesar $0,015<0,1$. Perusahaan yang mengalami kondisi financial distress pada umumnya memiliki rasio DTA yang tinggi dan menunjukkan jumlah utang yang hampir sama besar dengan total aktivanya dan bahkan ada perusahaan yang memiliki jumlah utang. Perusahaan yang mempunyai jumlah utang lebih besar daripada total aktivanya pada umumnya memiliki ekuitas yang negatif. Maka tidak menutup kemungkinan perusahaan yang memiliki jumlah utang yang cukup tinggi akan melanggar perjanjian utang dengan kreditur karena jumlah aktiva yang dimiliki tidak mampu menjamin 


\section{Jurnal Keuangan dan Perbankan | KEUANGAN}

Vol. 21, No. 2, April 2017: 265-275

utang yang dimiliki perusahaan dan perusahaan yang memiliki utang tinggi juga akan dibebankan biaya bunga yang tinggi sementara itu jumlah utang yang lebih tinggi daripada total aktiva perusahaan menyebabkan nilai buku ekuitas perusahaan negatif. Hasil penelitian ini juga sesuai dengan penelitian Almilia \& Kristijadi (2003) dan Pasaribu (2008), dan Hapsari (2012) yang menyatakan bahwa rasio leverage dapat digunakan dalam memprediksi kondisi financial distress.

\section{Kesimpulan}

Penelitian ini bertujuan untuk mengetahui pengaruh rasio keuangan untuk memprediksi probabilitas financial distress. Indikator rasio keuangan menggunakan rasio profitabilitas, rasio likuiditas, rasio aktivitas, dan rasio leverage. Berdasarkan pendahuluan, kajian teori dan pengolahan data yang telah dilakukan pada perusahaan sektor telekomunikasi yang terdaftar di Bursa Efek Indonesia (BEI) pada tahun 2009-2016. Maka dapat ditarik kesimpulan bahwa rasio likuiditas yang dikur dengan Current Ratio (CR) dan rasio aktivitas yang diukur dengan Total Asset Turnover (ATO) mempunyai pengaruh negatif dan signifikan dalam memprediksi financial distress. Rasio profitabilitas yang diukur dengan Return On Asset (ROA) mempunyai pengaruh positif dan signifikan dalam memprediksi financial distress dan rasio leverage yang dikur dengan Debt to Total Asset (DTA) mempunyai pengaruh positif dan signifikan dalam memprediksi financial distress.

\section{Saran}

Bagi pihak manajemen agar dapat digunakan sebagai dasar untuk melakukan tindakan-tindakan perbaikan jika telah ada indikasi bahwa perusahaan mengalami financial distress. Bagi investor agar dapat digunakan sebagai dasar dalam mengambil keputusan yang tepat untuk berinvestasi dalam suatu perusahaan. Dengan memperhatikan rasio profitabilitas, likuiditas, aktivitas dan leverage yang terbukti secara empiris dalam penelitian ini rasiorasio keuangan tersebut mampu memengaruhi financial distress.

Untuk penelitian selanjutnya sebaiknya menggunakan ukuran lain untuk memproksikan kondisi financial distress perusahaan atau menggunakan lebih dari satu proksi dalam menentukan financial distress seperti menggunakan interest coverage ratio, nilai buku ekuitas negatif, dan arus kas negatif, maupun menggunakan faktor ekonomi makro yang dapat digunakan untuk memprediksi kondisi financial distress perusahaan.

\section{DAFTAR PUSTAKA}

Afriyeni, E. 2012. Model Prediksi Financial Distress Perusahaan. Polibisnis, 4(2):1-10.

Agrawal, K. \& Maheshwari, Y. 2016. Predicting Financial Distress: Revisiting the Option Based Model, South Asian Journal of Global Business Research, 5(2):268-284.

Ahmad, G.N. 2013. Analysis of Financial Distress in Indonesian Stock Exchange. Review of Integrative Business and Economic Research, 2(2):521-533.

Al-khatib, H.B. \& Horani, A.A. 2012.Predicting Financial Distress of Public Companies Listed in Amman Stock Exchange. European Scientific Journal, 8(15):1-17.

Almilia, L. S. \& Kristijadi. 2003. Analisis Rasio Keuangan Untuk Memprediksi Kondisi Financial Distress Perusahaan Manufaktur yang Terdaftar di Bursa Efek Jakarta. Jurnal Akuntansi dan Auditing Indonesia (JAAI), 7(2):183-210.

Altman, E.I. 1968. Financial Ratio, Discriminant Analysis, and the Prediction of Corporate Bankruptcy. The Journal of Finance, 23(4): 589-609.

Azwar. 2015. Model Prediksi Financial Distress dengan Binary Logit. Badan Pelatihan dan Pendidikan Keuangan, 8(1): 1-23.

Beaver, W. H., Correia, M., \& McNichols, M.F. 2011. Financial Statement Analysis and the Prediction of Financial Distress. Foundations and Trends in Accounting, 5(2): 99-173. 


\section{Memprediksi Financial Distress dengan Binary Logit Regression Perusahaan Telekomunikasi}

Tiara Widya Antikasari \& Djuminah

Brahmana, R.K. 2007. Identifying Financial Distress Condition in Indonesia Manufacture Industry.Birmingham Business School. University of Birmingham. United Kingdom.

Ghozali, I. 2006. Aplikasi Analisis Multivariate Lanjutan Dengan Program SPSS. Edisi 1. Semarang: Badan Penerbit Universitas Diponegoro.

Giampaoli, V.,Tamura, K.A., Caro, N.P. \& Araujo, L.J.S. 2016. Prediction of A Financial Crisis in Latin American Companies using the Mixed Logistic Regression Model, Chilean Journal of Statistics, 7(1):31-41.

Hapsari, E.I. 2012. Kekuatan Rasio Keuangan dalam Memprediksi Kondisi Financial Distress Perusahaan Manufaktur di BEI. Jurnal Dinamika Manajemen, 3(2):101-109.

Hidayat, M.A. \& Meiranto, W. 2014. Prediksi Financial Distress Perusahaan Manufaktur di Indonesia. Diponegoro Journal of Accounting, 3(3):1-11.

Hill, N. T., Perry, S. E. \& Andes, S.1996. Evaluating Firms in Financial Distress: An Event History Analysis. Journal of Applied Business Research 12(3): 60-71.

Irfan, M. \&Yuniati, T. 2014. Analisis Financial Distress dengan Pendekatan Altman Z-Score untuk Memprediksi Kebangkrutan Perusahaan Telekomunikasi. Jurnal Ilmu \& Riset Manajemen, 3(1): 1-18.

Kasmir. 2008. Analisis Laporan Keuangan. Jakarta: PT Raja Grafindo Persada.

Lawrence J.R., Pongsatat, S. \& Lawrence, H. 2015. The Use of Ohlson's O-Score for Bankruptcy Prediction in Thailand. The Journal of Applied Business Research, 31(6): 2069-2078.
Nurfajrina, A., Siregar, H. \& Saptono, I.T. 2016. Analisis Financial Distress pada Perusahaan Agribisnis di Bursa Efek Indonesia. Jurnal Keuangan dan Perbankan, 20(3):448-457.

Ohlson, J. A. 1980. Financial Ratios and the Probabilistic Prediction of Bankruptcy. Journal of Accounting Research, 18(1): 109-131.

Pasaribu, R.B.F. 2008. Penggunaan Binary Logit untuk Prediksi Financial Distress Emiten di BEI. Jurnal Ekonomi Bisnis E Akuntansi Ventura, 11(2):153-172.

Pervan, I., Pervan, M. \& Vokuja, B.2011. Prediction of Company Bankruptcy using Statistical Techniques. Croatian Operational Research Review (CRORR), 2:158-167.

Putra, H. S. R. 2009. Manajemen Keuangan dan Akuntansi Untuk EksekutifPerusahaan. Jakarta: Salemba Empat.

Riyanto, B. 2011.Dasar-Dasar Pembelanjaan Perusahaan. Edisi Keempat.Yogyakarta: BPFE.

Syamsuddin, L. 2004. Manajemen Keuangan Perusahaan. Jakarta: PT Raja Grafindo.

Widarjo, W. \& Setyawan, D. 2009. Pengaruh Rasio Keuangan terhadap Kondisi Financial DistressPerusahaan Otomotif. Jurnal Bisnis dan Akuntansi, Vol. 11(2):107-119.

Widhiari, N.L.M.A. \& Merkusiwati, N.K.L.A. 2015. Pengaruh Rasio Likuiditas, Leverage, Opertaing Capacity, dan Sales Growth terhadap Financial Distress. E- Jurnal Akuntansi Universitas Udayana, 11(2):456-469.

Whitaker, R.B. 1999. The Early Stages of Financial Distress. Journal of Economics and Finance, 23: 123-133. 